\title{
A IMPLANTAÇÃO DA COLETA SELETIVA: UMA ESTRATÉGIA DE EDUCAÇÃO AMBIENTAL EM UM MUNICÍPIO DO RIO GRANDE DO SUL/RS
}

\author{
Suzy Elizabeth Pinheiro Canes ${ }^{1}$ \\ Andressa Rocha Lhamby $^{2}$ \\ Aline Soares Nunes ${ }^{3}$
}

\begin{abstract}
Resumo
Atualmente, a maioria das atividades desenvolvidas pela sociedade, em especial no meio urbano, são potencialmente geradoras de impactos ambientais negativos. Nesse contexto, destaca-se a problemática dos resíduos sólidos, que com o aumento da população tem sido agravada nos últimos anos. Para uma melhor destinação dos resíduos deve ser proposta uma política de recolhimento dos resíduos sólidos urbanos, que além da destinação correta dos resíduos, é capaz de construir uma população sustentável do ponto de vista social e ambiental, através da redução dos resíduos produzidos e da reutilização e reciclagem de materiais como alternativa de renda. O objetivo do presente trabalho é fazer um levantamento da situação dos resíduos sólidos produzidos em um município da região central do estado do Rio Grande do Sul que possui cerca de três mil habitantes, extensão territorial de cerca de mil $\mathrm{km}^{2}$ e a economia baseada na agropecuária como estratégia de educação ambiental. Baseado nos dados coletados realizou-se uma investigação das fontes geradoras de resíduos sólidos e sua destinação final.
\end{abstract}

Palavras-chave: Resíduos Sólidos Urbanos; Coleta Seletiva; Educação Ambiental.

\section{Objetivo}

O principal objetivo deste trabalho é realizar um levantamento das reais possibilidades de implantação da coleta seletiva no Município estudado como estratégia de educação ambiental. As atividades desenvolvidas basearam - se em: pesquisas bibliográfica respeito do tema; análise da situação dos resíduos sólidos e identificação da viabilidade da coleta seletiva na cidade estudada.

O município o qual se realizou a pesquisa localiza-se na metade Sul do Estado localizada na região da campanha, possui 2.352 habitantes e uma superfície territorial de $955 \mathrm{~km}^{2}$ (IBGE 2007), distante $295 \mathrm{~km}$ de Porto Alegre, capital do Estado. A economia baseia-se principalmente na agropecuária. As principais culturas são a soja e

\footnotetext{
1 Mestre Engenharia de Produção - UFSM; Professor Assistente Universidade Federal do Pampa - Campus São Gabriel; suzycanes@ unipampa.edu.br.

${ }^{2}$ Mestranda Engenharia de Produção - UFSM; andressalhamby@ hotmail.com.

3 Bacharel em Gestão Ambiental Universidade Federal do Pampa - Campus São Gabriel; alinesoaresnunes@hotmail.com.
} 
III SEMINÁRID ECDLOGIA

\section{PDLÍTICA}

A Associação Brasileira de Normas Técnicas (ABNT) NBR 10.004 (2004), faz as seguintes considerações à respeito de resíduos sólidos: resíduos nos estados sólido e semi-sólido, que resultam de atividades de origem industrial, doméstica, hospitalar, comercial, agrícola, de serviços e de varrição. Ficam incluídos nesta definição os lodos provenientes de sistemas de tratamento de água, aqueles gerados em equipamentos e instalações de controle de poluição, bem como determinados líquidos cujas particularidades tornem inviável o seu lançamento na rede pública de esgotos ou corpos de água, ou exijam para isso soluções técnica e economicamente inviáveis em face à melhor tecnologia disponível. De acordo com censo do IBGE (2008, 2010), a quantidade estimada diária de lixo urbano coletado no Brasil, segundo os grupos de tamanho dos municípios e a densidade populacional, é de 259547 toneladas, o que representaria $1,36 \mathrm{~kg}$ médios diários por cada um dos cerca de "190.732.694 habitantes". De um modo geral, os resíduos são constituídos por substâncias que podem ser classificadas conforme o seu grau de biodegradabilidade:

QUADRO 1 - Grau de Biodegradabilidade

\begin{tabular}{|l|l|}
\hline Substância & Características \\
\hline Facilmente Degradáveis (FD) & $\begin{array}{l}\text { Restos de comida, sobras de cozinha, folhas, } \\
\text { capim, cascas de frutas, animais mortos e } \\
\text { excrementos; }\end{array}$ \\
\hline Moderadamente Degradáveis (MD) & Papel, papelão e outros produtos celulósicos; \\
\hline Dificilmente Degradáveis (DD) & $\begin{array}{l}\text { Trapo, couro, pano, madeira, borracha, } \\
\text { cabelo, pena de galinha, osso, plástico! }\end{array}$ \\
\hline Não Degradáveis (ND) & $\begin{array}{l}\text { Metal não ferroso, vidro, pedras, cinzas, terra, } \\
\text { areia, cerâmica. }\end{array}$ \\
\hline
\end{tabular}

Fonte: FUNASA (2004). 

A coleta seletiva consiste na segregação e recolhimento de materiais descartados por empresas e domicílios, potencialmente recicláveis como: papéis, plásticos, vidros, metais e biodegradáveis, reduzindo desta forma, o encaminhamento para locais impróprios e sem a mínima estrutura para a sua disposição final, como lixões a céu aberto ou terrenos baldios (PENATTI e SILVA 2008).

\subsection{Educação Ambiental}

Nesse contexto, segundo Reigota (1998), a educação ambiental aponta para propostas pedagógicas centradas na conscientização, mudança de comportamento, desenvolvimento de competências, capacidade de avaliação e participação dos educandos. Para Pádua e Tabanez (1998), a educação ambiental propicia o aumento de conhecimentos, mudança de valores e aperfeiçoamento de habilidades, condições básicas para estimular maior integração e harmonia dos indivíduos com o meio ambiente.

A relação entre meio ambiente e educação para a cidadania assume um papel cada vez mais desafiador, demandando a emergência de novos saberes para apreender processos sociais que se complexificam e riscos ambientais que se intensificam.

As políticas ambientais e os programas educativos relacionados à conscientização da crise ambiental demandam cada vez mais novos enfoques integradores de uma realidade contraditória e geradora de desigualdades, que transcendem a mera aplicação dos conhecimentos científicos e tecnológicos disponíveis.

Quando se faz referência à educação ambiental, situamo-nos em contexto mais amplo, o da educação para a cidadania, configurando-a como elemento determinante para a consolidação de sujeitos cidadãos. O desafio do fortalecimento da cidadania para a população como um todo, e não para um grupo restrito, concretiza-se pela possibilidade de cada pessoa ser portadora de direitos e deveres, e de se converter, portanto, em ator co-responsável na defesa da qualidade de vida.

O principal eixo de atuação da educação ambiental deve buscar, acima de tudo, a solidariedade, a igualdade e o respeito à diferença através de formas democráticas de atuação baseadas em práticas interativas e dialógicas. Isto se consubstancia no objetivo 






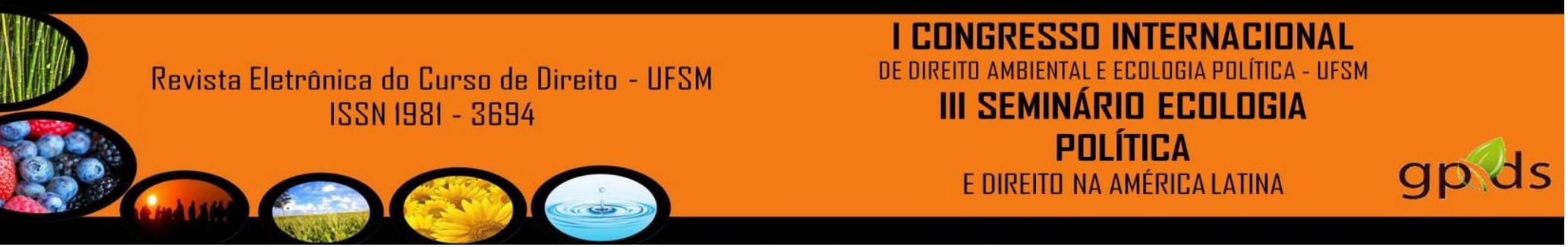

